\title{
Masjid Agung Kotagede: Kajian Awal Terhadap lnskripsi Yang Ada
}

\section{Muhammad Chawari}

Keywords: mosque, inscription, textual, archaeology, architecture

\section{How to Cite:}

Chawari, M. Masjid Agung Kotagede: Kajian Awal Terhadap lnskripsi Yang Ada. Berkala Arkeologi, 14(2), 31-33. https:// doi.org/10.30883/jba.v14i2.638

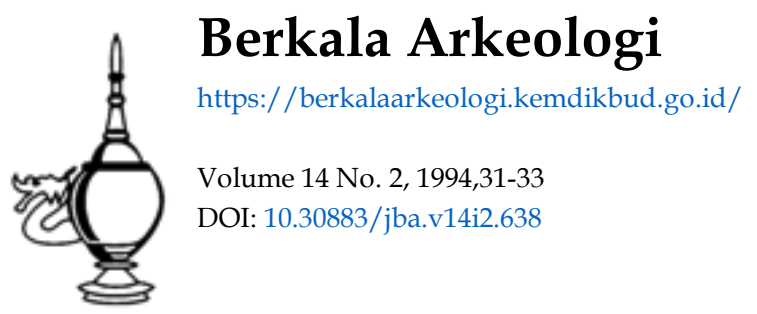

\section{cc) (i)(2)}

This work is licensed under a Creative Commons Attribution-NonCommercial-ShareAlike 4.0 International License. 


\title{
MASUID AGUNG KOTAGEDE \\ Kajian Awal Terhadap Inskripsi Yang Ada
}

\author{
Muhammad Chawari \\ (Balai Arkeologi Yogyakarta)
}

1. Pendahuluan
Kotagede merupakan salah satu kecamat an di Kotamadia Yogyakarta, yang terletak di sebelah tenggara kota. Dahulu Kotagede merupakan ibukota pertama kerajaan Mataram islam. Tempat inı merupakan daerah yang diberikan oleh Sultan Pajang (Hadiwijaya) kepada Ki Ageng Pemanahan sebagai hadiah (Brandes, 1894:415) atas kemenangannya terhadap Aria Penangsang dari Jipang. Oleh karena itu dapat dikatakan bahwa kerajaan Mataram inı dirintis oleh Ki Ageng Pemanahan, kemudian secara resmi didirikan oleh Panembahan Senopat yang menempati istananya di Kotagede. Daerah ini menjadi pusat pemerintahan pada masa Panembahan Senopati dan sebagian masa Sultan Agung. Pada masa Sultan Agung kraton dipindahkan ke Kerto (lbio).

Kemudian pada tahun $1648 \mathrm{M}$, yaitu masa pemerintahan Sunan Amangkurat I (1646-1677 M), kraton dipindahkan ke Plered, yang bejarak kurang lebih $1 \mathrm{~km}$ dari kraton yang lama (Adam, 1930:150-151). Beberapa tahun kemudian kraton dipindahkan lagi ke Kartasura. Pemindahan ke Kartasura in disebabkan oleh adanya pemberontakan Trunojoyo (Noto Suroto, 1985-1986:4-5).

Pada tahun $1742 \mathrm{M}$ terjadi geger Pacinan (pemberontakan orang-orang Tionghoa), dimana pemberontakan ini berhasil menggempur Kartasura. Oleh sebab itulah kraton dipindahkan lagı ke Surakarto (Pitojo, 1956:7). Satu bulan sesudah perjanjian Giyant, diumumkan berdirinya negara Ngayogyakarta dengan rajanya yaltu Sn Sultan Hamengku Buwana Senopati ing Alaga Ngabdurrahman Sayidin Panatagama Kalifatullah I ing Ngayogyakarta (Tashadi, 1979. 1880:34)

Pada setiap kota atau pusat pemerintahan sepertı tersebut di atas, setiap raja di samprng mendirikan kraton sebagai tempat kedudukan pemenntahan, juga menyuruh membangun masjid agung, misalnya Masjid Agung Kotagede. yang hingga sokarang masih dapat dilihat dan digunakan (Iiving monument).

Masjid ini dapat dicapai dengan mengambil jalan dan pasar Kotagede ke arah selatan kurang lebih 200 meter $\mathrm{Di}$ sisi kanan jalan tersebut terdapat kompleks masjid (serta makam). Di bagian depan kompleks terdapat dua bangsai, yaitu di kanan kıri jaian masuk. Di sebelah barat bangsal bagian selatan terdapat pohon beringin yang cukup besar Kedua bangsal tersebut sebenamya merupakan balai penerimaan yang disebut bangsal pasentulan (Djoko Soekıman, 1992/1993:5). Untuk memasuki kompleks masjid dan makam harus melewati pintu gerbang yang berbentuk paduraksa. Di bagian dalam pintu gerbang terdapat aling-aling, kelir, atau rana Halaman masjid cukup luas dan dikeliling। tembok. Masjid dan makam dengan halaman yang teduh dan tembok keliling secara keseluruhan merupakan kesatuan yang seras (lbid).

Secara garis besar data-data yang terdapat di Kotagede dapat dibedakan menjadi 3 macam, yaitu:

a. Data monumental, antara lain masjid Agung dan kompleks makam kuno di belakang masjid.

b. Data toponim, antara lain kedaton, alun-alun, samakan, pandeyan, mranggen, muthan mandarakan, dan purbayan

c. Data prasast, meliputi prasasts yang memakai huruf dan bahasa Arab serta Jawa Baru, baik yang terdapat di kompleks makam, sendang. maupun masjid.

Sesuai dengan judul dan sub judul, maka inskripsi yang akan diketengahkan adalah insknipsi yang terdapat di Masjid Agung Kotagede

\section{Transkripsi dan Arti}

Di kompleks kekunoan Kotagede banyak didapatkan prasasti, yang kebanyakan memakaı huruf dan bahasa Jawa. Namun demikian ada pula yang memakai huruf dan bahasa Arab. Insknpsi yang ada kaitannya dengan Masjid Agung Kotagede berjumlah tiga buah, dengan penncian satu buah memakai huruf dan bahasa Jawa Bar sedangkan dua yang lain memakai huruf dan bahasa Arab. Ketiga inskripsi tersebut terdapat pada dinding barat serambi bagian atas, dan dipahatkan di atas pintu tengah serambl yang menuju ke ruang inti. Di situ terdapat sebuah prasast yang memakai huruf dan bahasa Jawa Baru yang diapit oleh dua prasasti yang berhuruf dan bahasa Arab. Keoua prasasti yang memakai huruf dan bahasa Arab ini diberi bingkai berbentuk bulat memanjang.

\subsection{Inskrips yang memakaj hursf can bahasa Arab}

Inskripsı yang memakai huruf dan bahasa Arab di Masjid Agung Kotagede berjumlah 2 buah, yang keduanya mengapit inskripsi yang memakai huruf dan bahasa Jawa Baru. Kedua inskripsi tersebut yaitu: 
1. inskripsı di secelan kin (utara) inskripsi yang memakai huruf dan banasa Jawa Baru. Inskripsi ini terdiri atæs 2 beris, yang dipahatkan di dalam bingkai yang bertentuk culat memanjang.

Transkripsinja sbb:

a. hażal băisal masjidil haram fid därı tajul akbar

b. tabiâl baladil ak’’ar surakarta aitiningrat

Artinya sbb:

a Ini pintu (gerbang) Masjidil Haram (semısa) yang ada di Makkah) di dalam (wilayah) kerajaan (yang) besar

b. (yang) mengikuti (termasuk) negara (yang) besar (yaitu) Surakarta Adiningrat.

2. Inskripsi di sebelah kanan (selatan) insknpsi yang memakai huruf dan bahasa Jawa Baru. Inskripsi ini juga terdiri atas dua baris, yang dipahatkan juga di dalam bingkai yang verventuk bulat memanjang.

Transkripsinya sbb:

a. hijratun nabiyyu sad mim mim makaj ilal madinati

b. alfu wa miataini artoa'u wa saminu'na sanatin

Artinya sbb

a. Hijrahnya nabi salialiahu 'alaihı wasallam (Muhammad) dari Makkah ke Madinah

b tahun $1284 \mathrm{H}$

\subsection{Inskripsi yang mematai huruf dan bahasa Jawa Bary}

Inskripsi yang memakai huruf dan bahasa Jawa Baru di Masjid Agung Kotagede berjumlah 1 buah. Inskripsi ini terdapat di antara inskripsiinskripsi yang berhuruf dan bahasa Arab inskripsi in terdiri atas 2 baris

Transkripsinva sbb

a. Kamulyak haken tahun e-

b. he ngad(w)emken cipta karaning jalma Artinya sbb

a. Diperbaiki (pada) tahun $\theta$

b he $1796 \mathrm{~J}$

\section{Pembahasan}

Nenek moyang bangsa Indonesıa banyak mewarıskan peninggalan-peninggalan berupa bangunan-bangunan cand. Hindu maupun Buddha. stupa, pemandian, wihara, pertapaan dll. Di samping itu ada juga peninggalan-peninggalan purbakala lain yang bercorak Islam, antara laın masjid, istana, ataupun rumah tempat tinggal, serta kompleks pemakaman. Menurut Undang. undang Republik Indonesia No.5 tahun 1992 tentang Benda Cagar Budaya pada Bab I, Pasal 1 , Ayat la dikatakan bahwo benda buatan manusıa. bergerak atau tidak bergerak yang berupa kesatuan atau kolompok, atau bagian-bagiannya atau sisa-sisanya yang berumur sekurang-kurangnya 50 tahun, atau mewakili masa, gaya se- kurang-kurangnya 50 tahun, serta dianggap mempunyai nilai penting bagi sejarah, ilmu pengetahuan, dan kebudayaan termasuk Dengan demikian Masjid Agung benda cagar budaya Kotagede termasuk benda cagar budaya, yang dapat Jigolongkan sebagai monumen, karena besar dan megah serta tidak dapat dipindah-pindah.

Pada dasamya dalam setrap pemugaran monumen digunakian prinsip untuk mempertahankan bentuk, wajah, dan langgam aslinya sebanyak mungkin. Dengan kata lain, nılai purbakalanya sedapat mungkin dipertahankan Dari sejumiah monumen yang ada yang memeriukan teknik paling khusus dalam pemugarannya kebanyakan adalah warisan dari jaman indonesiaHindu. Monumen-monumen dari Jaman sesudahnya, antara lain masjid, gereja, serta gedunggedung lainnya tidak banyak menyimpang dari teknik umum (Sampoemo, 1976:44).

Sesuai dengan data dari ketiga inskrips! yang ada di Masjid Agung Kotagede diperoieh dua angka tahun yang berbeda. Pertedaan inı pada dasamya diakibatkan oleh adanya penggunaan huruf dan bahasa yang berbeda antara keduanya. Inskripsi yang berhuruf dan bahasa Arab menggunakan angka tahun hijrah $(H)$, sedangkan inskripsi berhusuf dan bahasa Jawa Baru memakai angka tahun jawa (J). Setelah disesuaikan (dicocokkan) beidasarkan tabel yang dibuat oleh $\mathrm{Dr}$. Th Pigeaud, ternyata kedua angka tahun tersebut sama.

Inskripsi yang berhuruf dan bahasa Arab menyebut angka tahun $1284 \mathrm{H}$, sedangkan inskripsi yang berhuruf dan bahasa Jawa Baru menyebut angka tahun dengan menggunakan sengkalan yang berbunyi ngad(w)emken cipta karaning jaima yang berarti angka tahun $1796 \mathrm{~J}$ Dengan demikian kedua angka tahun tersebut sebenarnya sama yaitu $1284 \mathrm{H}$, yang bertepatan dengan tahun $1796 \mathrm{~J}$ atau $1887 \mathrm{M}$ (Pigeaud. tanpa tahun)

Setelah diamati secara mendalam, ternyata tahun yang tertela di dalam inskripsı merupakan tahun pemugaran atau pembangunan kembaiı pintu gerbang masjid. Pemugaran ini dilakukan sehubungan dengan kerusakan-kerusakan yang terjadi pada saat itu, yaitu akibat adanya gempa bumi (H.J. van Mook, 1972:14). Berdasarkan prasasti yang ada di Masjid Besar Kauman Yogyakarte, Kota Yogyakarta pada tahun tersebut pemah digoyang gempa bumi yang hebat. Gempa bumi in mengakibatkan kerusakan pada sejumiah bangunan di Yogyakarta (Chawari, 1989:82,109) Salah satu contohnya adalah dengan dipugar atau diperbaikinya pintus gerbang pada Masijid Agung Kotagede. Dengan demikian tahun pemugaran pintu gerbang sama dengan tahun terjadinya gempa bumi yang menimpa Kota Yogyakarta 
Dengan kata lain pemugaran dilakukan saat itu juga setelah ter)adinya gempa bumi

Di samping itu, dari data inskripsi disebutsebut juga nama Surakarta Adiningrat Kasunanan Surakarta secara tidak langsung miengklaim bahwa pintu gerbang khususnya dan masjid pada umumnya merupakan bagian dari Kasunanan Surakarta Adiningrat, walaupun kenyataannya lokası Masjid Agung Kotagede berada di Yogyakarta. Dengan demikian dapat juga diartikan bahwa pemugaran pintu gerbang dilakukan oleh Kasunanan Surakarta. Hal ini mengingatkan pada kompleks makam imogiri dan kompleks makam Kotagede. Kedua kompleks pemakaman raja-raja Mataram Islam dan ketunjnannya tersebut secara umum dikelola, dirawat, dan dipelihara oleh dua kerajaan, yaitu Surakarta dan Yogyakarta, yang merupakan generasi penerus dari Kerajaan Mataram Isiam

\section{Kesimpulan}

Berdasarkan uraian-uraian tersebut di atas,

di bawah ini akan diketengahikan beberapa kesimpulan akhir dari tulisan ini

a. Tahun yang tertera di dalam kedua inskripsi (berhuruf dan bahasa Arab dan Jawa Baru) terdiri atas dua macam angka tahun yang berbeda, tetapi sebetuinya mengacu pada tahun yang sama Perbedaan tersebut disebabkan karena penggunaan dua macam pertanggalan, yaitu pertanggalan Jawa dan Hijrah (Hijriyah).

b. Tahun yang terterz di dalam kedua inskripsi merupakan tahun perbaikan atau pembangunan kembali pintu gerbang masjid, bukan tahun pendirian masjid seperti yang disinyalir sementara orang. Jika tahun tersebut dianggap sebagai tahun pendirian masjid, maka tahun itu terialu muda, yaitu tahun $1284 \mathrm{H}$ atau $1796 \mathrm{~J}$ atau $1867 \mathrm{M}$

c. Tahun terjadinya perbaikan atau pembangunan kembali pintu gerbang bersamaan waktunya dengan tahun terladinya gempa bumi di Yogyakarta. Hal itu terjadi karena pintu gerbang merupakan salah satu falktor pengaman yang penting bagi keberadaan sebuah masjid, sehingga perbaikan atau pembangunannya kembali harus segera dilakukan.

d. Kasunanan Surakaita Hadiningrat mengklaim bahwa pintu gerbang khususnya dan masjid pada umumnya merupakan bagian dari wewenang kekuasannya. Hal ini juga dapat diartikan bahwa yang membangun atau memperbaiki kembali pintu gerbang masjid tersebut adalah Kasunanan Surakarta Hadiningrat

\section{KEPUSTAKAAN}

Adam, L.. 1930, Eenige Historische en Legern darische Plaatsnamen in Jogiakarta Majalah DUAWA $X$

Brandes, J.L.A., 1984, Yogyaketia, TBG XXXVI

Djoko Soekiman, 1992/1993, Kotagede. Jakarta Proyek Pengembangan Media Kebudayaan Jakarta

Muhammad Chawari., 1989, Pasang Surut Masa Perkembangan Pembangunan Masijid Besar Kauman Yogyakarta. Studi Berdasakan Sumber Prasast. Yogyakarta: Skripsi Sarjana pada Jurusan Arkeologi Fakuttas Sastra Universitas Gadjah Mada

Noto Suroto., 1985/1986, Kesultanan Yogyakarta. Yogyakarta: Balai Kaıjan Sejarah Dan Nilai Tradisional

Pigeaud, Th., tanpa tahun, Javaans-Nedertands Handwoorden Boek Groningen: NV Wolters-Noordhoff.

Pitojo., 1956, Peristiwa peristiwa Ponting Kota Jogjakarta 200 Tahun 7 Oktober 1756 - 7 Oktober 1956. Yogyakarta: Panitia Peringatan Kota Jogjakarta 200 Tahun

Sampoemo, S., 1976, Pemugaran Candi. Jakarta Pusat Penelitian Purbakala Dan Peninggalan Nasional.

Tashadi., 1979/1980. Mengenal Bangunan Kraton Yogyakarta, Risalah Sejarah Dan Budaya Yogyakarta: Balai Penelitian Sejarah Dan Budaya

Undang-undang Republik Indonesia Nomer 5 Tahun 1992 Tentang Benda Cagar Budaye.

van Mook, H.J., 1972. Kuta Gede Djakarta Bhratara. 